\title{
Towards an integration of plant ecophysiological traits for the conservation of endangered species in ecosystems under water stress
}

\author{
Hacia una integración de los rasgos ecofisiológicos de las plantas para la \\ conservación de especies en peligro en ecosistemas sometidos a estrés hídrico
}

\author{
Felipe S. Carevic ${ }^{*}$
}

\begin{abstract}
Conservation of biodiversity in arid lands is a major issue worldwide. Knowledge of the biodiversity present is key to promote and facilitate the conservation of endangered native plants and will contribute to their persistence. The Atacama Desert, located in southern Peru and northern Chile, is considered a priority area for biodiversity conservation, principally due to high levels of endemism in the ecosystem. On this basis, water traits of plants are a useful tool for developing cause-and-effect relationships of abiotic variables under water stress environments. Nevertheless, currently there is lack of information about the influence of ecological factors on reproduction parameters, and the interaction among climatic variables and plant water relations that influence seed production in plants that inhabit water-limited environments. This report reviews the importance of incorporating plant physiology for the conservation of endangered vegetation as a predictive tool for management and preservation plans. Moreover, the report highlights the necessity of incorporating new protected areas, due the recent increase of species listed as endangered in the Atacama Desert. In brief, these two topics must be considered to promote the recovery of endangered biodiversity in hyperarid areas, taking into consideration soil erosion, climate change and industrialization processes.
\end{abstract}

Key words: Atacama desert, northern Chile, water limited environments.

\section{RESUMEN}

La conservación de la biodiversidad en las zonas áridas es un desafío importante en todo el mundo. El conocimiento de la biodiversidad presente es clave para promover y facilitar la conservación de plantas nativas en peligro de extinción, la cual contribuye a su persistencia. El desierto de Atacama, ubicado en el sur de Perú y norte de Chile, se considera un área prioritaria para la conservación de la biodiversidad, debido principalmente a los altos niveles de endemismo presentes en este ecosistema. Sobre esta base, las variables hídricas de las comunidades vegetacionales son una herramienta útil para el estudio de las relaciones de causa y efecto de los efectos del ambiente sobre los rasgos ecofisiológicos de las plantas. Sin embargo, en la actualidad existe una falta de información acerca de la influencia de los factores ecológicos sobre los parámetros de reproducción, y la interacción entre las variables climáticas y las relaciones hídricas de las plantas que influyen en la producción de semillas en las plantas que habitan en entornos limitados de agua. Esta revisión describe la importancia de incorporar las variables fisiológicas hídricas de la vegetación en peligro de extinción, como una herramienta predictiva para llevar a cabo planes de manejo y conservación. Por otra parte, se destaca la necesidad de incorporar nuevas áreas protegidas, debido al reciente aumento de las especies incluidas en peligro de extinción en el desierto de Atacama. Finalmente, se concluye que estos dos temas deben ser considerados para promover la recuperación de la biodiversidad en las zonas hiperáridas, teniendo en cuenta otras influyentes variables como la erosión del suelo, el cambio climático y los procesos de industrialización.

Palabras clave: desierto de Atacama, el norte de Chile, entornos limitados de agua.

\section{Introduction}

The protection of ecosystems is one of the greatest challenges faced by society. To address this governments have passed laws that limit negative impacts on ecosystems. Often these involve the development of conservation plans within each country, within which the conservation of biological diversity is often considered to be one of the most important priorities (Chape et al., 2008). Therefore, the protection of ecosystems is one of the greatest challenges faced by our societies. The important

\footnotetext{
1 Laboratorio de Ecofisiología Vegetal. Facultad de Recursos Naturales Renovables. Universidad Arturo Prat, Iquique, Chile. Campus Huayquique.

* Corresponding author: fcarevic@unap.cl
}

Fecha de Recepción: 13 Enero, 2016.

Fecha de Aceptación: 31 Marzo, 2016. 
factors related to the identification of priority restoration areas in degraded ecosystems and during the selection of an area due to its environmental fragility can be complex (Clewell and Aronson, 2013).

The effects of climate change in the region have been evaluated on an abiotic level, based on global data. They have predicted that in the near future there will be an increase in temperature, decrease in precipitation, and social migration will occur (Sheldon et al., 2011). Recent research has suggested that there will be significant warming over the entire region of the tropical Andes, with temperatures increasing $2-7^{\circ} \mathrm{C}$, depending on the location and scenario considered (Urrutia and Vuille, 2009). However, there have been few integral studies on the effects of these changes in abiotic factors on natural and agroforestry species in the ecosystems at the regional level. The most accepted hypothesis suggests that plants will undergo a series of physiological and morphological changes on their own that adapt to the new climate efficiently (Rundel et al., 2003; Parmesan, 2006). The future adaptations of natural ecosystems in the changing environment should be considered in management and conservation plans of native vegetation. Using the predicted climate change scenarios, it is necessary to analyze ecophysiological and conservation processes for the design of adaptation measures for the "Atacama Desert biodiversity" system. There is a lack of information about the influence of ecological factors on the reproductive process of plants and the effect of climatic parameters on their temporal variability. Plant species in the Atacama Desert have high ecological value, and their study and analysis often involves the quantification of flower production and seed production (SP). For example, SP plays a fundamental role in the regeneration of mesquite trees (Prosopis spp.) and the diet of local wildlife, such as the wild goat Capra aegagrus. At the whole-plant level, previous research on desert plants supports the theory that not only carbon assimilation, but also ecophysiological factors such as plant water relations and abiotic parameters could play an important role in SP (Sánchez-Humanes et al., 2011). The objectives of this report are (i) to review information collected from scientific studies regarding the effects of abiotic conditions on plant species under water stress, and (ii) to propose plant water variables as a predictor mechanism of seed production in arid plant species.

\section{Plant Physiology of Endangered Species}

\section{Limiting factors}

The largest world desert ecosystems are distributed in areas of Africa, southern USA and Chile. The Atacama Desert, located in southern Peru and northern Chile, is classified as a hyperarid desert, with areas that receive only $0.6 \mathrm{~mm} /$ year $^{-1}$ rain (Houston, 2006). In northern Chile, several priority areas for biodiversity conservation, including the Lluta River wetlands and Altiplano (of the Arica and Parinacota Region), Huasco Salar (in the Tarapaca Region) and Paposo (in the Antofagasta Region), have been identified as "natural biodiversity areas" due to the high number of endemic plant species present in each (INIA, 2011). However, the construction of the Chironta reservoir in Lluta, the isolation of Huasco Salar as a protected area and the construction of a power plant in Paposo all create risks for the preservation of the ecosystems.

According to INIA (2011), vegetation cover in Paposo has decreased remarkably. Berberis litoralis and Croton chilensis are two of the flagship species used to assess the ontogenetic characteristics of desert species in northern Chile. However, recently it has been difficult to obtain seedlings of these two species in Paposo, the causes of which are unknown. Some hypotheses point to high pollution of soils in the Taltal area, others to the heavy grazing by goats in the area, and some research has pointed to the shortage of rainfall as the dominant factor that has caused the population decline of these species (INIA, 2011).

Dry regions experience intense solar radiation, extreme air temperatures, low relative humidity, scant and unpredictable rainfall and low levels of primary productivity. Low water loss is the most important strategy of adaptation for organisms in these environments (Delatorre et al., 2008). The high heat loads and limited water supplies characteristic of the dry regions impose special demands on trees growing in them. Many xerophytes carry out most or all of their transpiration and growth during favorable periods of the year; however, a few species have adapted to desert conditions sufficiently to carry on transpiration throughout the hot, dry summer months (Rundel et al., 1994). In such extreme habitats there may be strong selection pressures on the physiological attributes of plants that live there, especially in terms of adjustments that minimize 
the rates of hydraulic conductivity and cuticular transpiration (Carevic, 2014).

\section{Plant Water Relations as a Predictive Tools}

Conservation physiology is a modern subdiscipline that involves the analysis of plant water traits of organisms as a useful tool to assess the impact of environmental variables on populations (Wikelski and Cooke, 2006). Likewise, xylem water potential $(\Psi)$ is one of the most important predictive physiological parameters for plants living in hyperarid zones; it provides insights into their adaptations to the extreme conditions typical of zones under water stress. For example, seasonal analyses of plant water efficiency in xeric ecosystems have been useful to investigate the role of abiotic parameters such as winter frosts and summer droughts (Granda et al., 2014). Unlike desert plants in the Northern Hemisphere, desert plants in the Atacama Desert have adapted to perform rapid growth and reproduction over short periods, when water is available (Rundel et al., 2003). The measurement of photosynthesis and water efficiency during the first months of growth in desert plants appears to be a useful strategy to increase understanding of the growth traits of seedlings (Pérez et al., 2015). The effects of drought stress and frost under natural conditions in plants have been extensively studied, and are often the topic of lively debate. Water and temperature are typically the limiting factors for vegetation in arid ecosystems, and an increase in soil humidity may increase plant biomass. In a recent study, Carevic et al. (2015) found that temperatures below $0{ }^{\circ} \mathrm{C}$ induced a significant decrease in specific leaf area (SLA) and an increase of the relative water content (RWC) in Prosopis burkartii, thus increasing leaf biomass. However, Mangla et al. (2011), found that the SLA in annual desert grasses was more related to soil nutrient content than climatic variables. Clearly, there is phenotypic plasticity in the responses of plants and these have not been sufficiently studied in those plants that have adapted to hyperarid ecosystems; it is necessary to evaluate these traits at inter-annual scales. In addition, it appears that physiological traits in plants can be used as predictors of other traits. For example, previous research in Mediterranean ecosystems found that low xylem water potential and a decrease in cuticular transpiration during summer months limited acorn production in Quercus ilex stands during autumn (Alejano et al., 2008; Carevic et al., 2010). Similarly, Moriana et al. (2007) concluded that water relations in drought-induced olive trees in a semiarid habitat had an effect on the concentration of phenolic compounds in the oil they produced. On this basis, the following question arises: is it possible to measure certain physiological variables in desert plants and predict leaf biomass or SP traits? This information could be valuable to establish potential risks of environmental health when low values of plant water relations are identified. Many authors have suggested that physiological parameters could be involved in SP, the most important productive process in plants. However, most research has focused on agroforestry species with economic benefits in terms of food supply. Some preliminary studies on arid species have considered the effect of water stress on photosynthesis and net $\mathrm{CO}_{2}$ uptake, but they did not consider the effect of physiological variables on reproductive processes such as SP (Nobel and De La Barrera, 2002; Delatorre et al., 2008).

\section{Genetic variability}

Desert plants exhibit high genetic variability at the intra- and inter-population levels, which may influence their capacity to respond to extrinsic factors such as weather, forestry activities or edaphic parameters (Stahlschmidt et al., 2011). In addition to producing different physiological responses, the high genetic variability of the desert plants induces differences in leaf size, biomass production and SP. $\mathrm{SP}$ is one of the main links between trees and soil, and is known to play a key role in nutrient cycling within agroforestry ecosystems. However, the process of SP in desert plants is not well understood, even though it is important from economic and ecological points of view. Seed abundance plays a fundamental role not only for the natural regeneration of plant species but also for wildlife that is dependent on shrubs and trees fruits for feeding (Perry and Thill, 2003). In the Chilean desert, lack of natural regeneration is one of the main problems for their sustainability in the long term (González et al., 2011; Jimenez et al., 2011). The economic value of the seed is mainly based on it being a source of food for livestock and natural fauna, which increases the added value of the desert ecosystem.

For several decades there has been a crisis in the natural regeneration of species in the Atacama ecosystems (Squeo et al., 2008). This might be 
attributed to the lack of pollinators and current climatic variations, which have been shown to cause a decrease in the population of both native species such as Dalea azurea (Fabaceae) in the Antofagasta region, and agroforestry species such as Prosopis sp. in the Tarapacá region (INIA, 2011; Carevic, 2014); both of these species are now considered critically endangered. Polylepis species are distributed in northern Chile and Bolivia; in northern Chile their populations are distributed across a wide elevational gradient between 3500 and 5000 meters above sea level. Therefore, they have adapted to different microhabitats with heterogeneous regimes of rainfall. Previously Polylepis tarapacana, a vulnerable species, was found to have high genetic diversity between populations (Schmidt et al., 2006). The high genetic variability found is likely a series of ontogenetic strategies within each population which adapt to each microhabitat. For example, the low temperatures at treeline restrict growth processes (meristem activities) in Polylepis spp., and the slope exposure, as well as the soil humidity, determines the distribution of this forest (Hoch and Korner, 2005). Thus different responses to abiotic conditions in these populations could be expected; these responses should result in high variability of seed production at intra- and inter-population levels.

\section{Conservation of the Atacama Desert}

Management of the natural heritage in northern Chile has mainly focused on carrying out actions aimed at conserving the main areas that contain surface waters, in the Pampa del Tamarugal ecosystem within the Tarapaca region (Squeo et al., 2006). There are various international cases that support this strategy, such as the Rio de Janeiro Convention of 1992 (Agenda 21). This was the first document that emphasized the importance and responsibility that the nations of the world have in saving and appreciating their environmental heritage (Mittermeier and Bowles, 1993). Currently, the term "biodiversity" encompasses a series of biological, cultural and environmental concepts. The conservation and management of biodiversity requires the adoption of a number of steps, through the use of innovative tools that take into account multiple aspects of ecosystems, such as environmental, economic and social aspects (González et al., 2011; Iverson et al., 2014;). There are currently no initiatives in the arid regions in northern Chile aimed at evaluating the natural heritage of the ecosystems, which are all at least partly degraded as a result of the industrial and demographic growth of cities (Oyarzún and Oyarzún, 2011). However, these regions possess a series of natural arid and hyperarid ecosystems which each constitute a unique scenario for conservation and restoration activities (Gutiérrez et al., 2008). Within the northern regions (I, II and XV) four different ecological zones are apparent: coastal, Pampa, Precordillera and Altiplano. Some of the species present in these ecosystems have been identified as vulnerable (Holmgren et al., 2006). In the Atacama Desert of northern Chile there has been an alarming increase in the identification of endangered vegetation in recent years. For example, in Paposo (in the Antofagasta region) at least 89 species are considered "threatened" by government environmental organizations (INIA, 2011). According to data from the Environment Department, the ecosystems that belong to the four ecological zones in the Tarapacá region contain nine species of native flora and fauna that are threatened, of which three are critically endangered, that is, one step away from extinction (Ministerio de Medio Ambiente, 2011; Carevic, 2014). The main causes of this process of extinction are anthropogenic intervention, climate change and the degradation of the ecosystems. The area has been subjected to continuous modifications, caused by mining industrialization and demographic expansion (Ormazabal, 1993). Clearly, a global analysis related to the ecological and physiological parameters of endangered plants in the north of Chile is required and more effort is needed in integrating biodiversity conservation and the creation of new areas of biodiversity protection.

\section{Future Challenges}

Arid and hyperarid ecosystems in the north of Chile form a special and unique natural scenario, and should have high conservation priority at the country level. The different ecosystems tend to be distributed in zones close to industrial activities or big cities that, on average, present high rates of population growth and constitute a direct threat to the natural ecosystems (Oyarzún and Oyarzún, 2011). The identification of potential areas for ecological restoration in the Arica and Parinacota, Tarapacá, and Antofagasta regions should be analyzed as a top priority, not only from an ecological point of view, but also from social and economic points of 
view, considering the ecosystem service functions that the natural resources offer to society. The most prominent climate change predictions for northern Chile under the SRES A2 (based on fast demographic growth) and B2 (based on moderate demographic growth) scenarios, include a rise of over $3{ }^{\circ} \mathrm{C}$ in average temperatures (IPCC, 2007). In the Altiplano the temperatures are predicted to rise during spring and summer, and in the marine environment, the sea level is predicted to increase by $0.2 \mathrm{~m}$ (Conama, 2007). A series of questions then arise that require analysis of the natural resources in the region and how they will adapt to the changing climate. A comprehensive study based on the predicted changes in the climate is necessary. Future studies should describe the potential physiological changes, both in situ and remotely, of plant species associated with the natural ecosystems under the predicted climate change scenarios.

\section{Acknowledgements}

The author acknowledges the valuable assistance offered by Vicerrectoría de Investigación, Innovación y Posgrado of Universidad Arturo Prat. This research was funded by FONDECYT, project number 11130242 .

\section{Literature Cited}

Alejano, R.; Tapias, R.; Fernández, M.; Torres, E.; Alaejos, J.; Domingo, J.

2008. Influence of pruning and the climatic conditions on acorn production in Holm oak (Quercus ilex L.) dehesas in SW Spain. Annals of Forest Science, 65: 209-215.

Carevic, F.; Fernández, M.; Alejano, R.; Vásquez-Piqué, J.; Tapias, R.; Corral, E.; Domingo, J.

2010. Plant water relations and edaphoclimatic conditions affecting acorn production in a holm oak (Quercus ilex L. ssp. ballota) open woodland. Agroforestry Systems, 78: 299-308.

Carevic, F.

2014. The role of ecophysiological studies in the genus Prosopis: implications for the conservation of drought prone species. Idesia, 32: 77-81

Carevic, F.; Delatorre, J.; Arenas, J.

2015. Physiological strategies during frost periods for two populations of Prosopis burkartii, an endangered species endemic to the Atacama desert. Journal of Arid Environments, 114: 79-83.

Chape, S.; Spalding, M.; Jenkins, M.

2008. The world's protected areas: status, values and prospects in the Twenty-first century. University of California Press, Berkeley. 388 p.

Clewell, A.; Aronson, J.

2013. Ecological restoration: principles, values, and structure of an emerging profession. $2^{\text {nd }}$ Edition. $336 \mathrm{p}$.

Conama.

2007. Estudio de la variabilidad climática en Chile para el siglo XXI. Universidad de Chile. 63 p.

Delatorre, J.; Pinto, M.; Cardemil, L.

2008. Effects of water stress and high temperature on photosynthetic rates of two species of Prosopis. Journal of Photochemistry and Photobiology b, 92: 67-76.

González, M.; Parra, M.; Huerta, M.; Ramírez, N.; Armesto, J.; Brown, A.; Echeverría, C.; Ferguson, B.; Geneletti, D.; Golicher, D.; Gowda, J.; Holz, S.; Ianni, E.; Kitzberger, T.; López-Barrera, F.; Malizia, L.; Manson, R.; Montero-Solano, J.; Montoya-Gómez, G.; Orsi, F.; Premoli, A.; Rey-Benayas, J.; Schiapacasse, I.; Smith-Ramírez, C.; Williams-Linera, G.; Newton, A.

2011. Development of policy recommendations and management strategies or restoration of dryland landscapes.
In: Principles and Practice of Forest Landscape Restoration: Case studies from the drylands of Latin America. Newton, A.C.; Tejedor, N. (Eds.) IUCN Gland, Switzerland, pp. 307-352.

Granda, E.; Scoffoni, C.; Rubio, A.; Sack, L.; Valladares, L.

2014. Leaf and stem physiological responses to summer and winter extremes of woody species across temperate ecosystems. Oikos, 123: 1281-1290.

Gutiérrez, A.; Barbosa, O.; Christie, D.; del Val, E.; Ewing, H.; Jones, C.; Marquet, P.; Weathers, K.; Armesto, J.

2008 Regeneration patterns and persistence of the fog-dependent Fray Jorge forest in semiarid Chile during the past two centuries. Global Change Biology, 14: 161-176.

Hoch, G.; Korner, C.

2005. Growth, demography and carbon relations of Polylepis trees at the world's highest treeline. Functional Ecology, 19: 941-951.

Holmgren, M.; Stapp, P.; Dickman, C.; Gracia, C.; Graham, S.; Gutiérrez, J.; Hice, C.; Jaksic, F.; Kelt, D.; Letnic, M.; Lima, M.; López, B.; Meserve, P.; Milstead, W.; Polis, G.; Previtali, M.; Ritcher, M.; Sabaté, S.; Squeo, F.

2006. Extreme climatic events shape arid and semiarid ecosystems. Frontiers in Ecology and the Environment, 4: 87-95.

Houston, J.

2006. Variability of precipitation in the Atacama desert: its causes and hydrological impact. International Journal of Climatology, 26: 2181-2198.

INIA.

2011. Implementación de un plan de conservación ex-situ, propagación y reintroducción de especies seleccionadas de la flora endémica del sitio prioritario sector costero de paposo y su entorno. Informe Final. 124 p.

IPCC.

2007. Climate change 2007: synthesis report. In: Core Writing Team. Pachauri, R.; Reisinger, A. (eds). Contribution of Working Groups I, II and III to the Fourth Assessment Report of the Intergovernmental Panel on Climate Change. IPCC, Geneva, pp. 104. 
Iverson, L.; Echeverría, C.; Nahuelhual, L.; Luque, S.

2014. Ecosystem services in changing landscapes: An introduction. Landscape Ecology, 29: 181-186.

Jiménez, M.; Jaksic, F.; Armesto, J.; Gaxiola, A.; Meserve, P.; Kelt, D.; Gutiérrez, J.

2011. Extreme climatic events change the dynamics and invasibility of semi-arid annual plant communities. Ecology Letters, 14: 1227-1235.

Mangla, S.; Sheley, R.L.; James, J.J.

2011. Field growth comparisons of invasive alien annual and native perennial grasses in monocultures. Journal of Arid Environments, 75: 206-210.

Ministerio de Medio Ambiente.

2011. Acta Sesión No 05 Octavo proceso clasificación de especies, $12 \mathrm{p}$.

Mittermeir, R.; Bowles, I.

1993. The global environment facility and biodiversity conservation: lessons to date and suggestions for future action. Biodiversity and Conservation, 2: 637-655.

Moriana, A.; Pérez-López, D.; Gómez-Rico, A.; Salvador, M.;

Olmedilla, N.; Riba, F.; Fregapane, G.

2007. Irrigation scheduling for traditional, low-density olive orchards: water relations and influence on oil characteristics. Agricultural Water Management, 87: 1171-1179.

Nobel, P.; De la Barrera, E.

2002. High temperatures and net $\mathrm{CO}_{2}$ uptake, growth, and stem damage for the hemiepiphytic cactus Hylocereus undatus. Biotropica, 34: 225-231.

Ormazábal, C.

1993. The conservation of biodiversity in Chile. Revista Chilena de Historia Natural, 66: 383-402.

Oyarzún, J.; Oyarzún, R.

2011. Sustainable development threats, inter-sector conflicts and environmental policy requirements in the arid, mining rich, northern Chile territory. Sustainable Development, 19: 263-274.

Parmesan, C.

2006. Ecological and evolutionary responses to recent climate change. Annual Review of Ecology and Systematics, 37: 637-669.

Pérez, R.; Flores, J.; Jurado, E.; González, C.

2015. Growth and ecophysiology of succulent seedlings under the protection of nurse plants in the Southern Chihuahuan Desert. Ecosphere, 6: 1-21.

Perry, R.; Thill, R.

2003. Initial effects of reproduction cutting treatments on residual hard mast production in the Ouachita mountains. Southern Journal of Applied Forestry, 27: 253-258.
Rundel, P.

1994. Tropical alpine climates and environments. In: Tropical Alpine Environments: Plant Form and Function. Rundel, P.; Smith, A.; Meinzer, F. (eds.). Cambridge University Press, Cambridge. pp. 21-44.

Rundel, P.; Gibson, A.; Midgley, G.; Wand, S.; Palma, B.; Kleier

C.; Lambrinos, J.

2003. Ecological and ecophysiological patterns in a preAltiplano shrubland of the Andean Cordillera in northern Chile. Plant Ecology, 169: 179-193.

Sánchez-Humanes, B.; Sork, V.; Espelta, J.

2011. Trade-offs between vegetative growth and acorn production in Quercus lobata during a mast year: the relevance of crop size and hierarchical level within the canopy. Oecologia, 166: 101-110.

Sheldon, K.; Yang, S.; Tewksbury, J.

2011. Climate change and community disassembly: impacts of warming on tropical and temperate montane community structure. Ecology Letters, 14: 1191-1200.

Schmidt-Lebuhn, A.; Kumar, M.; Kessler, M.

2006. An assessment of the genetic population structure of two species of Polylepis Ruiz et Pav. (Rosaceae) in the Chilean Andes. Flora, 201: 317-325.

Squeo, F.; Aravena, R.; Aguirre, E.; Pollastri, A.; Jorquera, C.; Ehleringer, J.

2006. Groundwater dynamics in a coastal aquifer in northcentral Chile: Implications for groundwater recharge in an arid ecosystem. Journal of Arid Environments, 67: 240-254.

Squeo, F.; Arancio, G.; Gutiérrez J.

2008. Libro Rojo de la Flora Nativa y de los Sitios Prioritarios para su Conservación: Región de Atacama. Ediciones Universidad de La Serena, La Serena. 468 p.

Stahlschmidt, Z.; DeNardo, D.; Holland, J.; Kotler, B.; Kruse-

Peebles, M.

2011. Tolerance mechanisms in North American deserts: Biological and societal approaches to climate change. Journal of Arid Environments, 75: 681-687.

Urrutia, R.; Vuille, M.

2009. Climate change projections for the tropical Andes using a regional climate model: Temperature and precipitation simulations for the end of the 21 st century. Journal of Geophysical Research, 114: 1823-1825.

Wikelski, M.; Cooke, S.

2006. Conservation physiology. Trends in Ecology \& Evolution, 21: $38-46$. 